\title{
Renewable Energy from Finite Resources: Example of Emerging Photovoltaics
}

\author{
Felix Schmidtab, Andreas Schäffer ${ }^{\mathrm{b}}$, and Markus Lenz ${ }^{\star a c}$
}

\begin{abstract}
Renewable energies, such as sunlight, wind and geothermal heat, are resources that are replaced rapidly by natural processes. However, wind, hydro and solar installations strictly require raw materials that are, in fact, not renewable. Many raw materials are already facing a supply shortage which cannot be easily overcome. This work reviews the problem of critical raw material (CRM) use in photovoltaics (PV) as an example and explains why supply cannot be easily increased to meet demand. We discuss whether there is indeed a 'struggle for elements' in a Darwinian sense, which ultimately leads to a 'survival of the fittest' race in renewable energy technology. In the case of PV, the perception of the definition of 'fittest' needs to change from that considering energy conversion efficiency alone to that which holistically considers net energy produced per emission under the premise that sufficient environmentally and socially acceptable raw material supply exists for renewable energies and all other sectors.
\end{abstract}

Keywords: Clean technologies · Critical raw materials $\cdot$ Secondary sources $\cdot$ Thin film photovoltaics

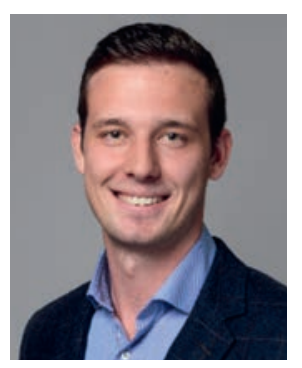

Felix Schmidt obtained his bachelor's and master's degrees in chemistry from ETH Zürich. He is now working as a PhD student in a joint programme between FHNW and RWTH Aachen University. His research focuses on the environmental assessment of perovskite $\mathrm{PV}$ with a particular interest in the fate of their heavy metal constituents.

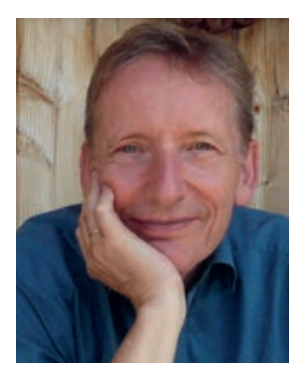

Andreas Schaeffer was trained as a chemist. After a research stay in industry, he became Professor of Environmental Biology and Chemodynamics at RWTH Aachen University. His research interests relate to the metabolism of organic xenobiotics, such as pesticides, pharmaceuticals and nanoparticles in soil, water, sediments and organisms. The overarching topic is the persistence and effect assessment of chemicals and products.

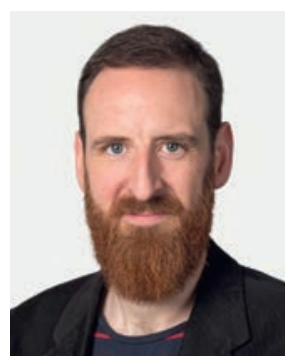

Markus Lenz is a senior researcher at the Institute for Ecopreneurship, FHNW. His main interests are the environmental fate of metals/metalloids, particularly redox-sensitive elements, such as Se, As and Sb. His group aims to exploit metal microbe interactions to control metal speciation for the remediation of contamination and the recovery and recycling of metals from secondary sources.

\section{Introduction}

Achieving climate neutrality is one of the major challenges our society is facing. The European Commission (EC) has called for a climate-neutral (i.e. net-zero emissions) society in Europe by 2050.[1] This was confirmed by the newly elected EC president Ursula von der Leyen, who has called for a reduction of $\mathrm{CO}_{2}$ emission of $50 \%$ or more by $2030 . .^{[2]}$ The energy sector is crucially entangled within this strategic development and renewable energy technologies are likely to play an increasing and essential role. Photovoltaics (PV) have already achieved a current cumulative installed capacity worldwide of about $400 \mathrm{GW}$, which contributed approximately $2.5 \%$ to the global electricity production in 2017. ${ }^{[3,4]}$

The PV market is growing rapidly by $+25 \%$ p.a. with an actual total installed capacity of around $400 \mathrm{GW} .{ }^{[5-8]}$ The market is dominated by Si-based technology, which comprises so-called first-generation solar cells and accounted for about $90 \%$ of the total PV energy production in 2017. ${ }^{[4]}$ Second-generation or thin-film technologies contributed roughly $10 \%$ of total annual electricity production from PV in 2017 (CdTe 5\% market share; $\mathrm{CuIn} \mathrm{Ga}_{(1-\mathrm{x})} \mathrm{Se}_{2}$, abbreviated CIGS) $2 \%$ market share). ${ }^{[9-11]}$ Over the past years, particular thin-film PV based on new absorber materials (third generation) have emerged, such as perovskite and organic solar cells ${ }^{[12,13]}$ (see Fig. 1). These have given rise to potential application outside the range of rigid glass wafer-based technology via roll-to-roll (R2R) and sheet-to-sheet (S2S) processing on flexible (PET) substrates. ${ }^{[14-17]}$

The current growth rate of the PV market suggests an unlimited (and exponential) increase in solar cell deployment. ${ }^{[4]}$ However, despite generally using less materials due to having intrinsically high absorption coefficients, ${ }^{[18]}$ second- and third-generation PV are still based on finite, inorganic materials to some extent. This condition could be limiting the PV capacity that can be installed in the future. Such limitations in technology deployment have 
A c-Si(TOPCon)

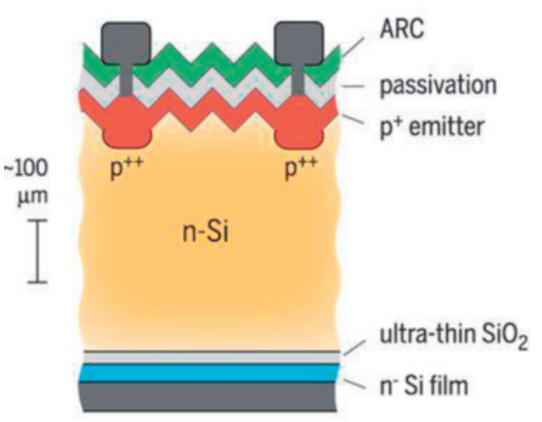

E GaAs

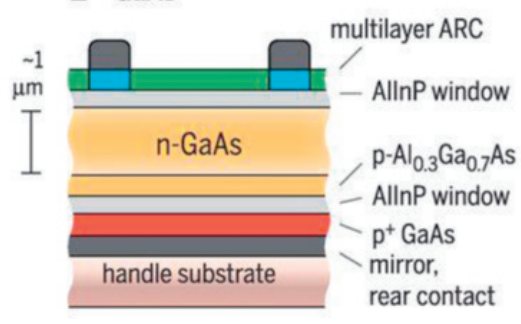

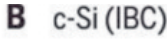

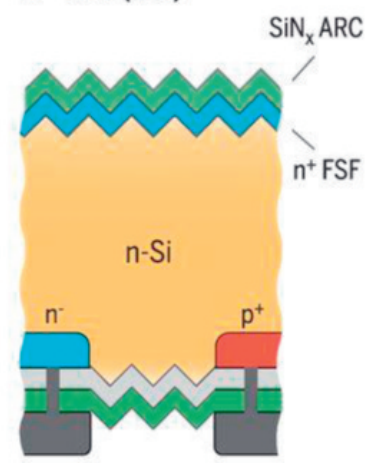

F CIGS

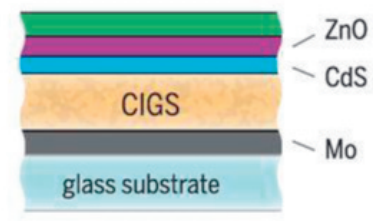

C $\mathrm{c}-\mathrm{Si}(\mathrm{IBC} \mathrm{SHJ})$

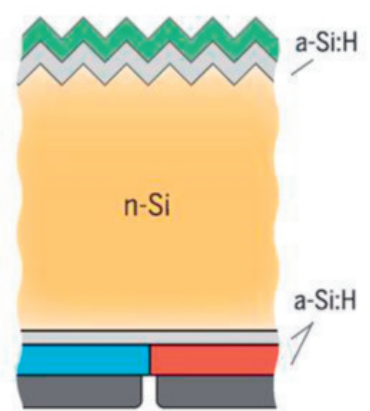

G CdTe

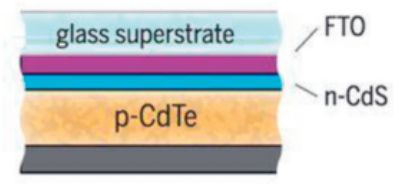

D $\mathrm{mc}-\mathrm{Si}$ (PERC)

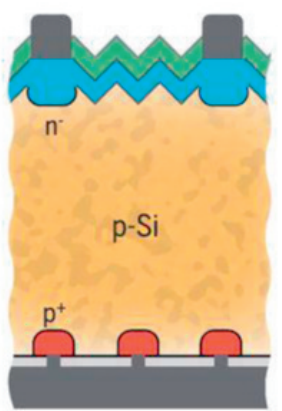

H Perovskite

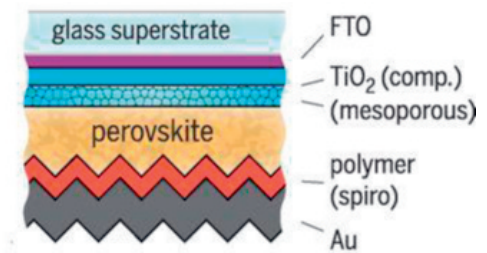

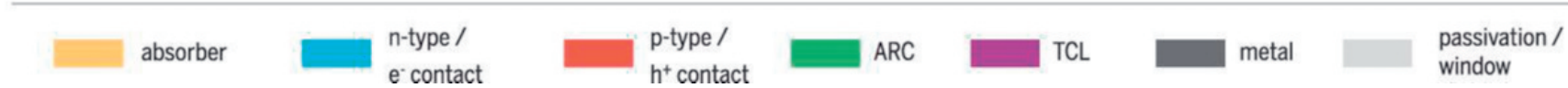

Fig. 1. Device architectures for different photovoltaic technologies from first (A-D), second (E-G) and third generation (H). From A. Polman, M. Knight, E. C. Garnett, B. Ehrler, W. C. Sinke, Science 2016, 352, 6283, DOI: 10.1126/science.aad4424. Reprinted with permission from AAAS.

already been encountered in some energy-related fields (e.g. Liion batteries and wind turbine magnets). ${ }^{[10,19-24]}$ Supply shortage is not a technological and economic problem alone; it involves a complex interplay between geopolitical, social and environmental factors. Thus, solving supply issues may be more difficult than merely 'opening the tap further'. The choice for a certain raw material in renewable energies should thus be based not only on technical performance but also (and more importantly) on a material's future availability and the social and environmental impacts associated with its supply. Therefore, this paper discusses the following questions related to finite materials in renewable energies.

- What are critical raw materials (CRMs), and which of them are used in renewable energies, particularly PV?

- How can the supply risk of CRMs be overcome?

- When is the use of a certain raw material in renewable energies justified?

- Is there competition for raw materials between different renewable energies?

- Is there competition for raw materials between renewable energies and other sectors?

\section{CRMs used in PV}

Raw materials are considered critical when their risk of supply shortage is above average and exerts an elevated impact on the economy. ${ }^{[25]}$ The economic importance of elements is briefly assessed by end-uses and value added to the European Union's (EU) manufacturing sectors. ${ }^{[26]}$ A substitution index is used to express the possibility of application-specific substitution. Furthermore, the supply risk of each CRM, in consideration of import reliance, governance performance and trade aspects of primary producers, and recycling are regarded as risk-reducing measures. ${ }^{[27]}$ Since 2011, the EC has been regularly publishing lists of CRMs. The most recent list (2017) consists of 27 materials ${ }^{[28]}$ (including heavy and light rare-earth elements and platinum group metals). The identified elements are closely linked to clean technologies in general and to PV in particular (Table 1). They are utilised as electrode materials ( $\mathrm{Ag}, \mathrm{Au}, \mathrm{In})$ or as constituents in electron or hole transporting layers ( $\mathrm{Sn}, \mathrm{Zn}$ ) or used in photoactive materials themselves (Pb, Si, Sn).

Although Si is the second most abundant element in the Earth's crust, it has been identified as a CRM by the EU. This is due to the fact that for semiconductor applications in PV or microelectronics, $\mathrm{Si}$ is not replaceable, and it is required in the form of high-purity polycrystalline silicon (up to $11 \mathrm{~N}=99.999999999 \%$ purity). ${ }^{29,30]}$ The global supply of silicon is dominated by China, and $73 \%$ of the silicon consumed by the EU is imported from non-EU countries. ${ }^{[28]}$ The supply risk of silicon metal may thus jeopardise the ambitious goal of establishing a carbon-neutral economy and underlines the necessity of alternative PV technologies.

There are currently two main competitors for classical Si PV on the market, ${ }^{[31,32]}$ namely, CIGS and CdTe PV. These incorporate a range of inorganic raw materials, namely, $\mathrm{Cu}, \mathrm{In}, \mathrm{Ga}, \mathrm{Se}$, $\mathrm{Cd}$ and Te. Amongst these materials, In and Ga are considered CRMs. ${ }^{[9]}$ Apart from being applied in the active layer of CIGS, indium is commonly used in transparent conducting electrodes (ITO/FTO $)^{[33,34]}$ due to its unique electronic conductivity and optical transparency, ${ }^{[35,36]}$ and it can be regarded as one of the most crucial constituents of third-generation PV. Organic materials (e.g. PEDOT:PSS and CNTs) have been applied as potential substitutes in electrodes, ${ }^{[37]}$ yet technical performance may be compromised due to solubility issues and moisture instability. ${ }^{[38-40]}$ Mainly driven by flat-panel displays (most commonly LCDs; $~ 80 \%$ ), thin-film applications have become the predominant In end-use (as ITO). ${ }^{[41]}$ Indium is mostly extracted as a by-product from residues of zinc ore (sphalerite) processing, ${ }^{[42]}$ which causes considerable price volatility. Indium can be recovered from flat-panel displays by combinations of manual/ mechanical pre-treatment and acid leaching or vaporisation followed by purification via solvent extraction, electrowinning or smelting. ${ }^{[43]}$ Indium extraction rates from WEEE are usually only around $80 \%$, but purification processes can recover nearly $99 \%$ of indium. ${ }^{[44,45]}$ Gallium is a key component in GaAs and CIGS $\mathrm{PV}$ and consumes $\sim 4 \%$ of the globally generated $\mathrm{Ga} .{ }^{[46]}$ It is pro- 
Table 1. Inorganic raw materials used in photovoltaic applications

\begin{tabular}{|c|c|c|c|c|c|}
\hline Element & Use in PV & $\begin{array}{l}\text { mine production world } \\
2018 \text { [metric tons] }\end{array}$ & $\begin{array}{l}\text { world reserves }^{\mathrm{c}} \\
\text { [metric tons] }\end{array}$ & $\begin{array}{l}\text { EOL-RR } \\
{[\%]}\end{array}$ & $\begin{array}{l}\text { Critical raw } \\
\text { material EU? }\end{array}$ \\
\hline $\mathrm{Si}$ & Si PV & 6’700'000 & n.a. ${ }^{\mathrm{f}}$ & $<1$ & Yes \\
\hline $\mathrm{Cu}$ & CIGS PV & 21’000’000 & $830 ’ 000 ’ 000$ & $>50$ & No \\
\hline In & $\begin{array}{l}\text { CIGS PV, transparent conducting } \\
\text { oxide in most PK PV }\end{array}$ & $750^{\mathrm{a}}$ & n.a. & $<1$ & Yes \\
\hline $\mathrm{Ga}$ & GaAs PV, CIGS PV & 410 & n.a. & $<1$ & Yes \\
\hline As & GaAs PV & $35^{\prime} 000$ & $>700^{\prime} 000$ & $<1$ & No \\
\hline $\mathrm{Se}$ & CIGS PV, SbSe PV & 2800 & 99’000 & $<1$ & No \\
\hline $\mathrm{Cd}$ & CdTe PV & $26^{\prime} 000^{a}$ & $>69^{\prime} 000^{\mathrm{e}}$ & $>10-25$ & No \\
\hline $\mathrm{Te}$ & CdTe PV & 440 & $31^{\prime} 000$ & $<1$ & No \\
\hline $\mathrm{Zn}$ & electron transport layer, CZTS PV & $13^{\prime} 000 ’ 000$ & $230^{\prime} 000{ }^{\prime} 000$ & $>50$ & No \\
\hline $\mathrm{Sb}$ & SbSe PV & $140^{\prime} 000$ & $1500^{\prime} 000$ & $1-10$ & Yes \\
\hline $\mathrm{Ge}$ & III-V multi-junction PV & $120^{\mathrm{a}}$ & n.a. & $<1$ & Yes \\
\hline $\mathrm{Pb}$ & Perovskite B cation & $4^{\prime} 4000^{\prime} 000$ & $83^{\prime} 000 ’ 000$ & $>50$ & No \\
\hline $\mathrm{Sn}$ & $\begin{array}{l}\text { Transparent conducting oxide, } \\
\text { Perovskite B cation }\end{array}$ & $310^{\prime} 000$ & $4^{\prime} 700 ’ 000$ & $>50$ & No \\
\hline $\mathrm{Rb}$ & Perovskite A cation & n.a. & $90^{\prime} 000^{\mathrm{b}}$ & n.a. & No \\
\hline Cs & Perovskite A cation & n.a. & $90^{\prime} 000^{\mathrm{b}}$ & n.a. & No \\
\hline $\mathrm{Li}$ & dopant HTM in perovskites & $85^{\prime} 000$ & $14^{\prime} 000 ’ 000$ & $<1$ & No \\
\hline I & Perovskite $\mathrm{X}$ anion & 29’000 & 6’300’000 & n.a. & No \\
\hline $\mathrm{P}$ & Dopant, HTM constituent & $270 ’ 000 ’ 000$ & 70’000’000’000 & $<1$ & Yes \\
\hline $\mathrm{Au}$ & $\begin{array}{l}\text { Electrode material, double } \\
\text { perovskite }\end{array}$ & 3260 & $54^{\prime} 000$ & $>50$ & No \\
\hline $\mathrm{Ag}$ & Electrode material & $27^{\prime} 000$ & $560 ’ 000$ & $>50$ & No \\
\hline
\end{tabular}

arefinery production; bas oxide; 'economic extraction is currently feasible/potentially feasible; ${ }^{d}$ end-of-life recycling rate (EOL-RR) for functional recycling (as metal or alloy) only; classes: <1 \%; 1-10\%; >10-25\%;>25-50\%;>50\%; 'based on $0.03 \%$ Cd content in Zn ores; ${ }^{\mathrm{f}} \mathrm{n}$.a. not analyzed

duced mainly as a by-product from aluminium extraction and zinc ore processing. ${ }^{[47]}$ Currently, only around $10 \%$ of aluminium producers recover $\mathrm{Ga}$, and this condition is the main bottleneck in Ga supply.[28] Due to criticality of Ga and In, some attempts have been made to replace CIGS by copper zinc tin sulphide (CZTS)-based thin-film solar cells. ${ }^{[48,49]}$ SbSe- and Ge-based PV require CRMs (Table 1); however, they remain exclusively used in niche applications. ${ }^{[50,51]}$ All the other inorganic materials employed in PVs (Table 1) are not yet classified as CRMs for the overall economy.

\section{Ways to Overcome Supply Risk}

Supply risks can be mitigated by increasing primary production and/or implementing 3R strategies (reduction of consumption, recycling, reuse of resources). Increasing primary production appears straightforward, given the resources in the Earth's crust. However, there are many technological, social and environmental bottlenecks in this technique (as reviewed elsewhere ${ }^{[52]}$ ). Even if prerequisites were met, the investment cost of opening a new mine with a separation unit can still easily range between 500 million and 1 billion US\$, ${ }^{[52]}$ which is an often prohibitive initial capital investment. Consequently, many mines are viable only through co-mining operations that entangle the wanted element with other (typically unrelated) industries. Selenium, for example, is commercially produced as a by-product during the refinement of copper (and, to a lesser extent, nickel); it is not obtained as a primary ore. ${ }^{[42]}$ Consequently, selenium supply follows the production volumes of the primary elements $\mathrm{Cu}$ and/or Ni. In the past, the imbalance between supply and demand has resulted in extreme fluctuations in Se prices. ${ }^{[53]}$ Thus, Se-containing PV (CIGS, SbSe) may be economically compatible only when copper demand is high and selenium supply is consequently sufficient. Thin-film PV already follow the principle of reduction of consumption; only minute amounts of materials are used (compared to quantities of Si in first-generation PV), given the direct band gap and high absorption coefficients intrinsic to the absorber materials. Nonetheless, absorber layer thickness needs to be sufficient for the efficient absorption of incoming photons limiting further material reduction. Substitution of raw materials, if possible at all, usually compromises technical performance. For instance, in perovskite $\mathrm{PV}$, replacing $\mathrm{Pb}$ with $\mathrm{Sn}$ decreases the power conversion efficiency $(\mathrm{PCE})^{[54]}$ and/or stability. ${ }^{[55]}$ Furthermore, the recycling of raw materials may not only tackle supply risks but also decrease the end-of-life environmental im- 
pact. However, although mature PV materials are already being recycled (e.g. CdTe- and Si-based PV), ${ }^{[56,57]}$ every new PV technology requires considerable developmental work for recycling due to their fundamentally different module structures, raw material composition and/or final application (e.g. placement in a solar park, integration in buildings or use in consumer products). ${ }^{[58]}$ Although recycling is generally considered desirable, the energy used and emissions generated need to be balanced with the savings in primary production, which will compromise the recycling of some raw materials that are present in minute amounts in PV. In summary, supply risks will continue to persist for some CRMs despite the implementation of $3 \mathrm{R}$ strategies and increases in primary production.

\section{4. 'Struggle for Elements', Survival of the Fittest and Evolution of Sectors Employing CRMs}

Darwin's theory of evolution is a well-known biological concept that can be applied within the context of CRMs used in different applications and sectors. In evolution theory, the number of offspring is too large to be sustained by finite resources. This situation results in a 'struggle for life' ${ }^{[59]}$ and, ultimately, the 'survival of the fittest' ${ }^{[60]}$ and evolution of new species. CRMs have a large number of applications in different sectors, but these resources are finite. Thus, certain applications will also face a 'struggle for life'. Darwin's theory considers competition within a species. ${ }^{[61]}$ By contrast, the competition for a material can occur both within one sector (intrasectoral, e.g. energy production) and between different sectors (intersectoral). Intrasectoral competition may occur with regard to indium, which is utilised both as ITO electrodes and in the photoactive layer of CIGS (Table 1). Furthermore, the energy sector could compete for $\mathrm{Cs}$, since its primary use is in high-pressure, high-temperature well drilling for oil and gas production and exploration. ${ }^{[62]}$ Some intersectoral competitions are well known; for example, $\mathrm{Li}$ is used in automotive and consumer electronics in addition to being utilised as PV dopant. Many interconnections are being discovered only upon the progress of technological development and changes in geopolitical conditions. A competition of specific concern is that between renewable energies and agriculture. $\mathrm{P}$ and $\mathrm{Se}$ are both essential elements and thus irreplaceable in crop, food and feed production. Whereas only minute amounts of $\mathrm{P}$ are used for the doping of $\mathrm{PV},{ }^{[63]}$ Se constitutes the active layers of CIGS and SbSe PV. Some estimations show that up to 1 billion people may already be affected by Se deficiency. ${ }^{[64,65]}$ In this scenario, it would be cynical to call for additional Se-based PV technologies to combat man-made climate change because doing so will risk human and animal health through trace element deficiency.

\section{5. 'Tunnel View' of Technical Performance}

PV development is primarily driven by increased PCE and lifetimes at reduced costs. The ultimate goal of PV is to generate more energy than that used for the ultimate provision and maintenance of complete PV systems (modules, cables, electronic equipment). Given all the processes from raw material winning to endof-life recycling, energy payback times (EPBT) can be calculated and different PV systems compared. ${ }^{[9]}$ Despite having low $(<5 \%)$ PCE, some technologies have EPBT that are in the order of days due to energy- and material-efficient production. ${ }^{[66,67]}$ Researchers have tools at hand to evaluate the sense (or lack thereof) of using different materials and architectures from a technical view (i.e. energetic performance). Considering EPBT during technological development is a good approach, but it neglects social and environmental performance.

In first chemistry lectures, it is already taught that 'the dose makes the poison'. While this statement is certainly true, public perception and discussion of the risk of chemicals and elements are often dominated by emotions rather than rationality.
Therefore, public acceptance of technologies is crucial and needs to be assessed proactively. Some of the raw materials contained in PV are elements that are known as toxicants by the general public. The most prominent example is $\mathrm{Pb}$ in perovskite $\mathrm{PV}$. Although technically performing well (i.e. high PCE, good stability and EPBTs in the order of a few months ${ }^{[68,69]}$ ), perovskite solar cells still rely crucially on the use of $\mathrm{Pb}$ and/or $\mathrm{Sn}$. Lead, which has been banned from fuel additives, ${ }^{[70]}$ remains a problem in paint ${ }^{[71,72]}$ and old pipes ${ }^{[73]}$ and has recently drawn considerable media attention due to the Flint scandal. ${ }^{[74]}$ Thus, $\mathrm{Pb}$ is a much more prominent contaminant than, for instance, Te, despite the higher oral toxicity of Te. ${ }^{[75]}$ Similarly, some Sn (organo-Sn species in anti-fouling paints) species have strong ecotoxicological effects ${ }^{[76]}$ and have been banned in many countries since the 1980s. ${ }^{[77]}$ Note that for customer acceptance, it may be irrelevant that Sn in PPV is utilised as inorganic species (i.e. not having the same ecotoxicological effects) or that $\mathrm{Pb}$ does not leach out during the operation of a PV module. The amount of $\mathrm{Pb}$ that will actually leach from an installation ${ }^{[78]}$ and how this compares with the natural $\mathrm{Pb}$ emissions of other sources of energy ${ }^{[79]}$ are necessary considerations, but still not convincing to actual customers 'not wanting any $\mathrm{Pb}$ on my roof'. Limiting direct $\mathrm{Pb}$ exposure with worst-case-scenario back-up plans together with appropriate and efficient recycling schemes can help overcome these problems to some extent. Environmental performance is partly coupled with social acceptance and technological performance. A short EPBT suggests a comparatively low energy demand for the provision of PV systems. This will generally reduce the emissions of energy generation despite the source of energy having a profound impact on the overall environmental performance. ${ }^{[80,81]}$ Costs, which are incurred through energy provision and emission abatement, correlate with potential environmental impact to a certain degree. Nonetheless, not all environmental burden is associated with material/process prices, particularly when production under poor environmental governance (especially regarding metals) is considered.

Lifecycle assessment (LCA) provides a decision-making tool that can give 'endpoints' with environmental relevance, such as global warming potential and human and ecosystem toxicity.[68,82,83] Typically, metallic raw materials (Table 1 ) receive high impacts throughout all toxicity categories, since mining activities are energy intensive and related to the generation of large volumes of hazardous wastes. ${ }^{[84]}$ Alternatives such as carbon paste may result in low PCE but also reduce environmental impacts. ${ }^{69}$ ] Every model is based on certain assumptions and has its limits. An assessment with direct experiments is required to confirm predictions from LCA analysis and to provide insights into processes that cannot be modelled yet. Kinetics will determine the fate of critical PV constituents in complex, environmental systems, and appropriate laboratory and field experiments are required.

\section{Conclusion}

Renewable energies, such as wind, hydro and solar installations, critically require raw materials that are finite. Increasing primary production is only one approach to mitigating raw material supply risks, and strategies of reducing, reusing and recycling materials are urgently needed. Nonetheless, a 'struggle for elements' in a Darwinian sense may cause some renewable energies to not be adopted due to intersectoral and/or intrasectoral competition. For the development of successful renewable technologies, focus has to shift from mostly technical indicators used in material sciences (e.g. PCE and lifetime for PV) to net energy produced per emission caused during the whole life cycle. This change in focus should be under the premise that there is sufficient environmentally and socially acceptable raw material supply for all sectors. 


$\begin{array}{ll}\text { Abbreviations } \\ \text { CdTe } & \text { Cadmium telluride } \\ \text { CIGS } & \text { Copper indium gallium selenide } \\ \text { CNT } & \text { Carbon nanotubes } \\ \text { CRM } & \text { Critical raw material } \\ \text { CZTS } & \text { Copper zinc tin sulfide } \\ \text { EPBT } & \text { Energy payback time } \\ \text { FTO } & \text { Fluorine-doped tin oxide } \\ \text { GaAs } & \text { Gallium arsenide } \\ \text { ITO } & \text { Indium tin oxide } \\ \text { LCA } & \text { Lifecycle assessment } \\ \text { LCD } & \text { Liquid-crystal display } \\ \text { PCE } & \text { Power conversion efficiency } \\ \text { PEDOT:PSS } & \text { Poly(3,4-ethylenedioxythiophene) polystyrene sulfonate } \\ \text { PET } & \text { Polyethylene terephthalate } \\ \text { PV } & \text { Photovoltaic } \\ \text { R2R } & \text { Roll-to-roll } \\ \text { S2S } & \text { Sheet-to-sheet } \\ \text { SbSe } & \text { Antimony selenide } \\ \text { WEEE } & \text { Waste electrical and electronic equipment } \\ \text { Acknowledgements } \\ \text { This } & \text { project has received funding from the } \\ \text { European } & \text { Union's Horizon 2020 framework pro- } \\ \text { gramme for } & \text { research and innovation under grant } \\ \text { agreement No } & \text { 763977 of the PerTPV project. } \\ \end{array}$

Received: August 28, 2019

[1] The Commission calls for a climate neutral Europe by 2050, https:// ec.europa.eu/clima/news/commission-calls-climate-neutral-europe-2050 en, accessed August 10, 2019.

[2] Opening Statement in the European Parliament Plenary Session by Ursula von der Leyen, Candidate for President of the European Commission, https://europa.eu/rapid/press-release_SPEECH-19-4230_en.htm, accessed August 5, 2019.

[3] Solar Energy, https://www.iea.org/topics/renewables/solar/, accessed August 5, 2019.

[4] ISE, 'Photovoltaics Report', 2019.

[5] W. Hoffmann, Sol. Energy Mater. Sol. Cells 2006, 90, 3285.

[6] N. M. Haegel, R. Margolis, T. Buonassisi, D. Feldman, A. Froitzheim, R. Garabedian, M. Green, S. Glunz, H.-M. Henning, B. Holder, I. Kaizuka, B. Kroposki, K. Matsubara, S. Niki, K. Sakurai, R. A. Schindler, W. Tumas, E. R. Weber, G. Wilson, M. Woodhouse, S. Kurtz, Science 2017, 356, 141.

[7] D. B. Needleman, J. R. Poindexter, R. C. Kurchin, I. M. Peters, G. Wilson, T. Buonassisi, Energy Environ. Sci. 2016, 9, 2122

[8] IEA, 'Trends in Photovoltaic Applications 2018', 2018.

[9] K. P. Bhandari, J. M. Collier, R. J. Ellingson, D. S. Apul, Renew. Sustain. Energy Rev. 2015, 47, 133.

[10] V. M. Fthenakis, H. C. Kim, E. Alsema, Environ. Sci. Technol. 2008, 42, 2168.

[11] H. C. Kim, V. Fthenakis, J.-K. Choi, D. E. Turney, J. Ind. Ecol. 2012, 16, S110.

[12] M. A. Green, A. Ho-Baillie, H. J. Snaith, Nat. Photonics 2014, 8, 506.

[13] H. J. Snaith, J. Phys. Chem. Lett. 2013, 4, 3623.

[14] M. Kaltenbrunner, M. S. White, E. D. Glowacki, T. Sekitani, T. Someya, N. S. Sariciftci, S. Bauer, Nat. Commun. 2012, 3, 770.

[15] J. You, Z. Hong, Y. Yang, Q. Chen, M. Cai, T.-B. Song, C.-C. Chen, S. Lu, Y. Liu, H. Zhou, Y. Yang, ACS Nano 2014, 8, 1674.

[16] C. Roldán-Carmona, O. Malinkiewicz, A. Soriano, G. M. Espallargas, A. Garcia, P. Reinecke, T. Kroyer, M. I. Dar, M. K. Nazeeruddin, H. J. Bolink, Energy Environ. Sci. 2014, 7, 994.

[17] R. Søndergaard, M. Hösel, D. Angmo, T. T. Larsen-Olsen, F. C. Krebs, Mater. Today 2012, 15, 36.

[18] T. D. Lee, A. U. Ebong, Renew. Sustain. Energy Rev. 2017, 70, 1286.

[19] K. S. Stegen, Energy Policy 2015, 79, 1.

[20] D. J. Packey, D. Kingsnorth, Resour. Policy 2016, 48, 112.

[21] R. Schulze, M. Buchert, Resour. Conserv. Recycl. 2016, 113, 12.

[22] P. C. Sauer, S. Seuring, J. Clean. Prod. 2017, 151, 235.

[23] K. Jenkins, D. McCauley, A. Forman, Energy Policy 2017, 105, 631.

[24] R. Saidur, N. A. Rahim, M. R. Islam, K. H. Solangi, Renew. Sustain. Energy Rev. 2011, 15, 2423.

[25] G. A. Blengini, P. Nuss, J. Dewulf, V. Nita, L. T. Peirò, B. Vidal-Legaz, C. Latunussa, L. Mancini, D. Blagoeva, D. Pennington, M. Pellegrini, A. Van Maercke, S. Solar, M. Grohol, C. Ciupagea, Resour. Policy 2017, 53, 12.
[26] L. Mancini, L. Benini, S. Sala, Int. J. Life Cycle Assess. 2018, 23, 726.

[27] G. A. Blengini, 'Methodology for Establishing the EU List of Critical Raw Materials: Guidelines', Brussels, Belgium, 2017.

[28] EU Commission, 'Study on the Review of the List of Critical Raw Materials', 2017.

[29] D. Sarti, R. Einhaus, Sol. Energy Mater. Sol. Cells 2002, 72, 27.

[30] J. Safarian, G. Tranell, M. Tangstad, Energy Procedia 2012, 20, 88.

[31] M. A. Green, J. Mater. Sci. Mater. Electron. 2007, 18, 15.

[32] A. Jäger-Waldau, Int. J. Photoenergy 2012, 768368.

[33] W. Cao, J. Li, H. Chen, J. Xue, J. Photonics Energy 2014, 4, 40990.

[34] H. Liu, V. Avrutin, N. Izyumskaya, Ü. Özgür, H. Morkoç, Superlattices Microstruct. 2010, 48, 458.

[35] H. Kim, a C. M. Gilmore, A. Pique, J. S. Horwitz, H. Mattoussi, H. Murata, Z. H. Kafafi, D. B. Chrisey, J. Appl. Phys. 1999, 86, 6451.

[36] R. Bel Hadj Tahar, T. Ban, Y. Ohya, Y. Takahashi, J. Appl. Phys. 1998, 83, 2631.

[37] A. Kumar, C. Zhou, ACS Nano 2010, 4, 11.

[38] K. Sun, S. Zhang, P. Li, Y. Xia, X. Zhang, D. Du, F. H. Isikgor, J. Ouyang, J. Mater. Sci. Mater. Electron. 2015, 26, 4438.

[39] H. Shi, C. Liu, Q. Jiang, J. Xu, Adv. Electron. Mater. 2015, 1, 1500017.

[40] L. Hu, J. Li, J. Liu, G. Grüner, T. Marks, Nanotechnology 2010, 21, 155202.

[41] K.-S. Park, W. Sato, G. Grause, T. Kameda, T. Yoshioka, Thermochim. Acta 2009, 493, 105

[42] G. Gunn, 'Critical metals handbook', John Wiley \& Sons, 2014.

[43] F. Ardente, F. Mathieux, M. Recchioni, Resour. Conserv. Recycl. 2014, 92, 158.

[44] K. Zhang, Y. Wu, W. Wang, B. Li, Y. Zhang, T. Zuo, Resour. Conserv. Recycl. 2015, 104, 276

[45] D. Pradhan, S. Panda, L. B. Sukla, Miner. Process. Extr. Metall. Rev. 2018, 39, 167.

[46] T. H. Nguyen, M. S. Lee, Miner. Process. Extr. Metall. Rev. 2018, 1

[47] F. Lu, T. Xiao, J. Lin, Z. Ning, Q. Long, L. Xiao, F. Huang, W. Wang, Q. Xiao, X. Lan, H. Chen, Hydrometallurgy 2017, 174, 105.

[48] X. Song, X. Ji, M. Li, W. Lin, X. Luo, H. Zhang, Int. J. Photoenergy 2014, 613173 .

[49] Z. Su, W. Li, G. Asim, T. Y. Fan, L. H. Wong, in '2016 IEEE 43rd Photovoltaic Specialists Conference (PVSC)', 2016, pp. 534.

[50] O. S. Hutter, L. J. Phillips, K. Durose, J. D. Major, Sol. Energy Mater. Sol. Cells 2018, 188, 177.

[51] M. A. Green, K. Emery, Y. Hishikawa, W. Warta, E. D. Dunlop, Prog. Photovoltaics Res. Appl. 2015, 23, 1.

[52] D. Schüler, M. Buchert, R. Liu, S. Dittrich, C. Merz, 'Study on rare earths and their recycling', 2011.

[53] M. Lenz, P. N. L. Lens, Sci. Total Environ. 2009, 407, 3620.

[54] M. Konstantakou, T. Stergiopoulos, J. Mater. Chem. A 2017, 5, 11518.

[55] W. Liao, D. Zhao, Y. Yu, C. R. Grice, C. Wang, A. J. Cimaroli, P. Schulz, W. Meng, K. Zhu, R.-G. Xiong, Y. Yan, Adv. Mater. 2016, $28,9333$.

[56] R. Deng, N. L. Chang, Z. Ouyang, C. M. Chong, Renew. Sustain. Energy Rev. 2019, 109, 532.

[57] Recycling Strategy, http://www.firstsolar.com/en-EMEA/Modules/ Recycling, accessed August 20, 2019.

[58] K. Komoto, J. S. Lee, J. Zhang, D. Ravikumar, P. Sinha, A. Wade, G. Heath, IEA PVPS Task 12, Int. Energy Agency Power Syst. Program. Rep. IEAPVPS T12 2018, 10.

[59] C. Darwin, 'On the origin of species, 1859', Routledge, 2004.

[60] D. B. Paul, J. Hist. Biol. 1988, 21, 411.

[61] M. A. Huston, M. A. Huston, 'Biological diversity: the coexistence of species', Cambridge University Press, 1994.

[62] S. K. Howard, in 'SPE Annual Technical Conference and Exhibition', 1995.

[63] D. Yan, A. Cuevas, J. Bullock, Y. Wan, C. Samundsett, Sol. Energy Mater. Sol. Cells 2015, 142, 75.

[64] A. Haug, R. D. Graham, O. A. Christophersen, G. H. Lyons, Microb. Ecol. Health Dis. 2007, 19, 209.

[65] A. J. Hurd, R. L. Kelley, R. G. Eggert, M.-H. Lee, MRS Bull. 2012, 37, 405.

[66] S. Lizin, S. Van Passel, E. De Schepper, W. Maes, L. Lutsen, J. Manca, D. Vanderzande, Energy Environ. Sci. 2013, 6, 3136.

[67] N. Espinosa, M. Hösel, D. Angmo, F. C. Krebs, Energy Environ. Sci. 2012, $5,5117$.

[68] J. Gong, S. B. Darling, F. You, Energy Environ. Sci. 2015, 8, 1953.

[69] I. Celik, Z. Song, A. J. Cimaroli, Y. Yan, M. J. Heben, D. Apul, Sol. Energy Mater. Sol. Cells 2016, 156, 157.

[70] P. L. Barlow, Ind. Lubr. Tribol. 1999, 51, 128.

[71] A. Turner, E. R. Kearl, K. R. Solman, Sci. Total Environ. 2016, 544, 460.

[72] D. O'Connor, D. Hou, J. Ye, Y. Zhang, Y. S. Ok, Y. Song, F. Coulon, T. Peng, L. Tian, Environ. Int. 2018, 121, 85.

[73] P. Jarvis, K. Quy, J. Macadam, M. Edwards, M. Smith, Sci. Total Environ. 2018, 644, 1346.

[74] D. C. Bellinger, N. Engl. J. Med. 2016, 374, 1101.

[75] J. Zayed, S. Philippe, Int. J. Toxicol. 2009, 28, 259.

[76] P. E. Gibbs, G. W. Bryan, J. Mar. Biol. Assoc. UK 1986, 66, 767.

[77] R. Dalley, 'Correspondence: Legislation affecting tributyltin antifoulings', Taylor \& Francis, 1989. 
[78] B. Hailegnaw, S. Kirmayer, E. Edri, G. Hodes, D. Cahen, J. Phys. Chem. Lett. 2015, 6, 1543.

[79] D. Fabini, J. Phys. Chem. Lett. 2015, 6, 3546.

[80] I. Celik, A. B. Philips, Z. Song, Y. Yan, R. J. Ellingson, M. J. Heben, D. Apul, IEEE J. Photovoltaics 2017, 8, 305.

[81] D. Hengevoss, C. Baumgartner, G. Nisato, C. Hugi, Sol. Energy 2016, 137, 317
[82] I. Celik, A. B. Phillips, Z. Song, Y. Yan, R. J. Ellingson, M. J. Heben, D. Apul, Energy Environ. Sci. 2017, 10, 1874

[83] N. Espinosa, L. Serrano-Luján, A. Urbina, F. C. Krebs, Sol. Energy Mater. Sol. Cells 2015, 137, 303.

[84] J. Krook, N. Svensson, M. Eklund, Waste Manag. 2012, 32, 513. 